\title{
28. MIOCENE EVAPORITES IN RED SEA CORES, THEIR RELEVANCE TO THE PROBLEM OF THE WIDTH AND AGE OF OCEANIC CRUST BENEATH THE RED SEA
}

\author{
Ron W. Girdler, School of Physics, The University, Newcastle Upon Tyne \\ and \\ Robert B. Whitmarsh, National Institute of Oceanography, Wormley, Godalming, Surrey, United Kingdom
}

\section{INTRODUCTION}

Although it is generally accepted that the deep axial trough of the Red Sea has been formed by sea-floor spreading, there are considerable doubts and conflicting views on how the remainder of the Red Sea has been formed. The problem is heightened by the finding of early Pliocene sediments and late Miocene evaporites (older than 5 m.y.) at DSDP Sites 227 and 228 near the axial trough (Figure 1) where the age of the underlying oceanic crust predicted from magnetic anomalies is much younger (less than 2.5 m.y.)!

There are currently three views on the amount of oceanic crust beneath the Red Sea: (1) only the axial trough is underlain by oceanic crust (Girdler, 1958; Drake and Girdler, 1964; Hutchinson and Engels, 1970, 1972; Lowell and Genik, 1972; Ross and Schlee, in press); (2) the whole of the Red Sea was formed by sea-floor spreading (McKenzie et al., 1970); and (3) a compromise view that considerably more than the axial trough but not the whole of the Red Sea is underlain by oceanic crust (Girdler, 1966, 1970; Girdler and Darracott, 1972). This last is strongly dependent on the measured shear along the Dead Sea rift (Freund et al., 1970) and the positions of the 500-fathom isobaths in the northern Red Sea.

The findings at Sites 227 and 228 seem, on first sight, not to favor the second and third views because of the conflict of ages noted above. On the other hand, in recent years, evidence has been increasing for a much greater separation of Arabia from Africa than just the width of the Red Sea axial trough.

This contribution examines the case for greater separation and attempts to give an explanation for the presence of "older" sediments resting on "newer" oceanic crust at Sites 227 and 228.

\section{HISTORY AND DEVELOPMENT OF THE RED SEA}

\section{Geological Evidence}

Recent reviews of the geology have been given by Girdler (1969) and Coleman (this volume). Briefly, the main Red Sea graben is generally thought to have formed in stages. The first major rift movements have been assigned to the lower/middle Eocene, and there was basaltic volcanicity in the middle and upper Oligocene. Major rifting occurred in the lowermost Miocene and further movements in the uppermost Miocene (when the Red Sea became connected to the Gulf of Aden). The latter movements have continued through the Pliocene and Pleistocene to the present day.

Coleman (this volume) notes that pre-Miocene sediments are rare. Occasional marine Oligocene sediments have been drilled, but it was not until the Miocene that widespread sedimentation prevailed. Many exploration wells on the margins have penetrated 2 to $4 \mathrm{~km}$ below sea level and have revealed a sequence of marine lower and middle Miocene sediments overlain by thick evaporites (including massive salt), and these are overlain by detrital sediments. Interlayered Miocene basalts have been found in the southern Red Sea.

\section{Regional Plate Tectonics}

A full discussion of African poles of rotation has been given by Girdler and Darracott (1972). To obtain the mean Red Sea pole (separation of Arabia and Nubia) two lines parallel to, but $52 \mathrm{~km}$ seaward of the present Red Sea coasts, were fitted. This figure was obtained from consideration of estimates for the amount of shear along the Dead Sea rift (Freund et al., 1970) and for the amount of extension across the Suez rift (Robson, 1970). From this work, the directions and amounts of extension for various localities in the Red Sea can be estimated. For example, at the latitude of Site 228, the amount of extension is estimated to be $225 \mathrm{~km}$ in a direction $\mathrm{N} 50^{\circ}$. It is noted that not all this need be in the form of crustal separation, some of it can be taken up by associated thinning of the lithosphere.

Unfortunately, the timing of the movement is not well established. For the Dead Sea rift, Freund et al. (1970) report that several rock bodies of Miocene and possibly up to early Pliocene age are offset by $40-45 \mathrm{~km}$ but the earlier $60-65 \mathrm{~km}$ of offset can only be determined as postCretaceous. Taking the Miocene/Pliocene boundary at 5 m.y., this implies that the mean velocity along the Dead Sea shear zone over the last $5 \mathrm{~m} . \mathrm{y}$. is 0.8 to $0.9 \mathrm{~cm} / \mathrm{yr}$. The whole $105-\mathrm{km}$ offset may have been effected continuously at this rate but it is of course possible that there was more than one phase of movement.

It should also be mentioned that the poles of rotation for the Gulf of Aden and Red Sea are close together (Figure 2 ), and both the Gulf of Aden and Red Sea have formed by separation of Arabia from Africa in a roughly northeastsouthwesterly direction. Consideration of the consequences for the movement between Nubia and Somalia (the Ethiopian rift) shows that there is a small amount of extension but little or no shear. This is in agreement with the lack of geological evidence for any appreciable shear along the Ethiopian rift and implies that to a first order the development of the Gulf of Aden and Red Sea should have been similar.

\section{Magnetic Anomalies}

Over the Gulf of Aden, the magnetic anomalies are well mapped (Laughton et al., 1970), but over the Red Sea, mapping of the anomalies away from the axial trough by 

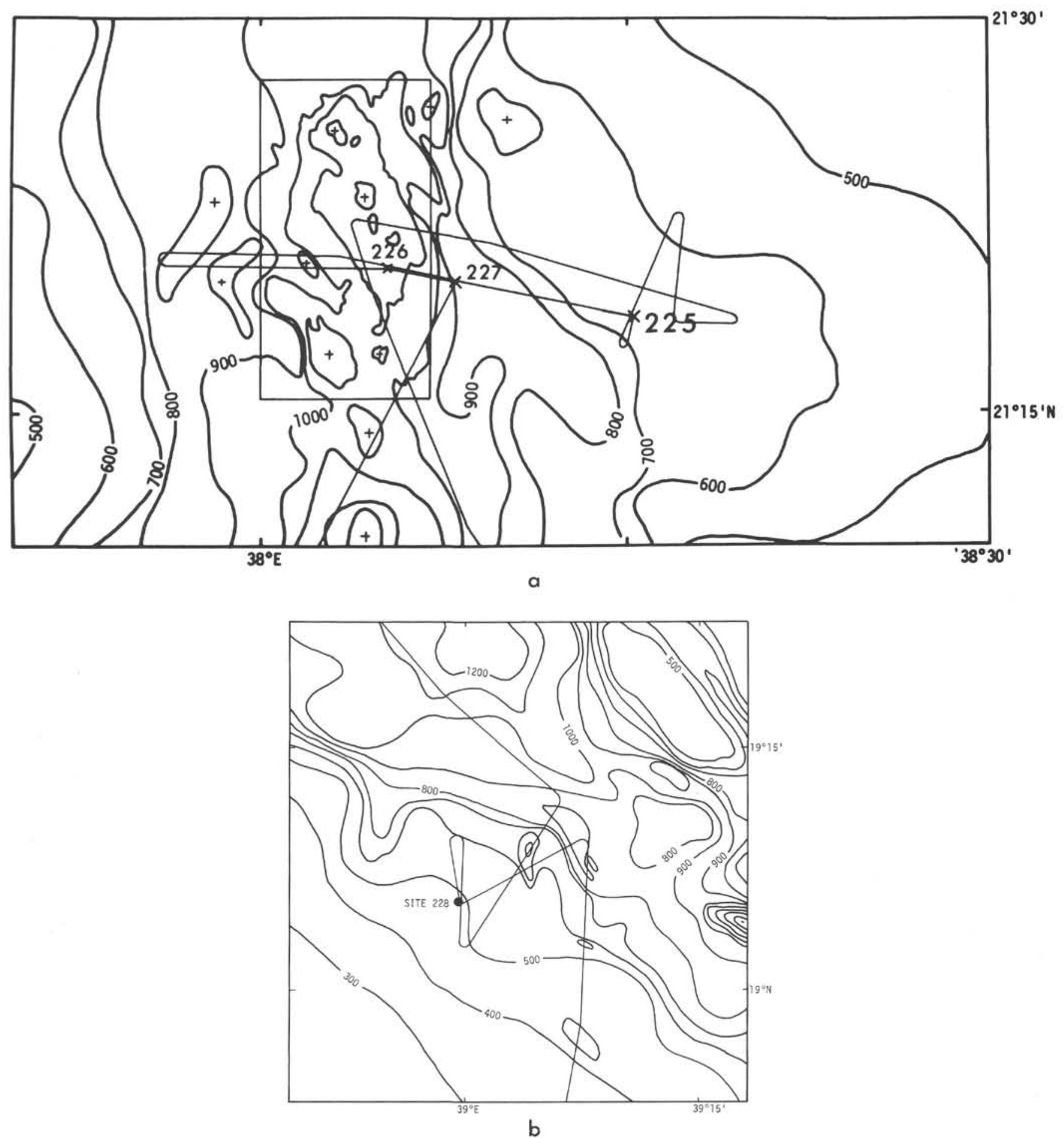

Figure 1. Bathymetric charts showing the positions of (a) Sites 225, 227 and (b) Site 228 relative to the axial trough of the Red Sea, with the tracks of Glomar Challenger. Contour interval 100 fathoms, depths in corrected fathoms. Based on collected soundings (after Laughton, unpublished). Contours within box of Fig. la from Amann (1972). 


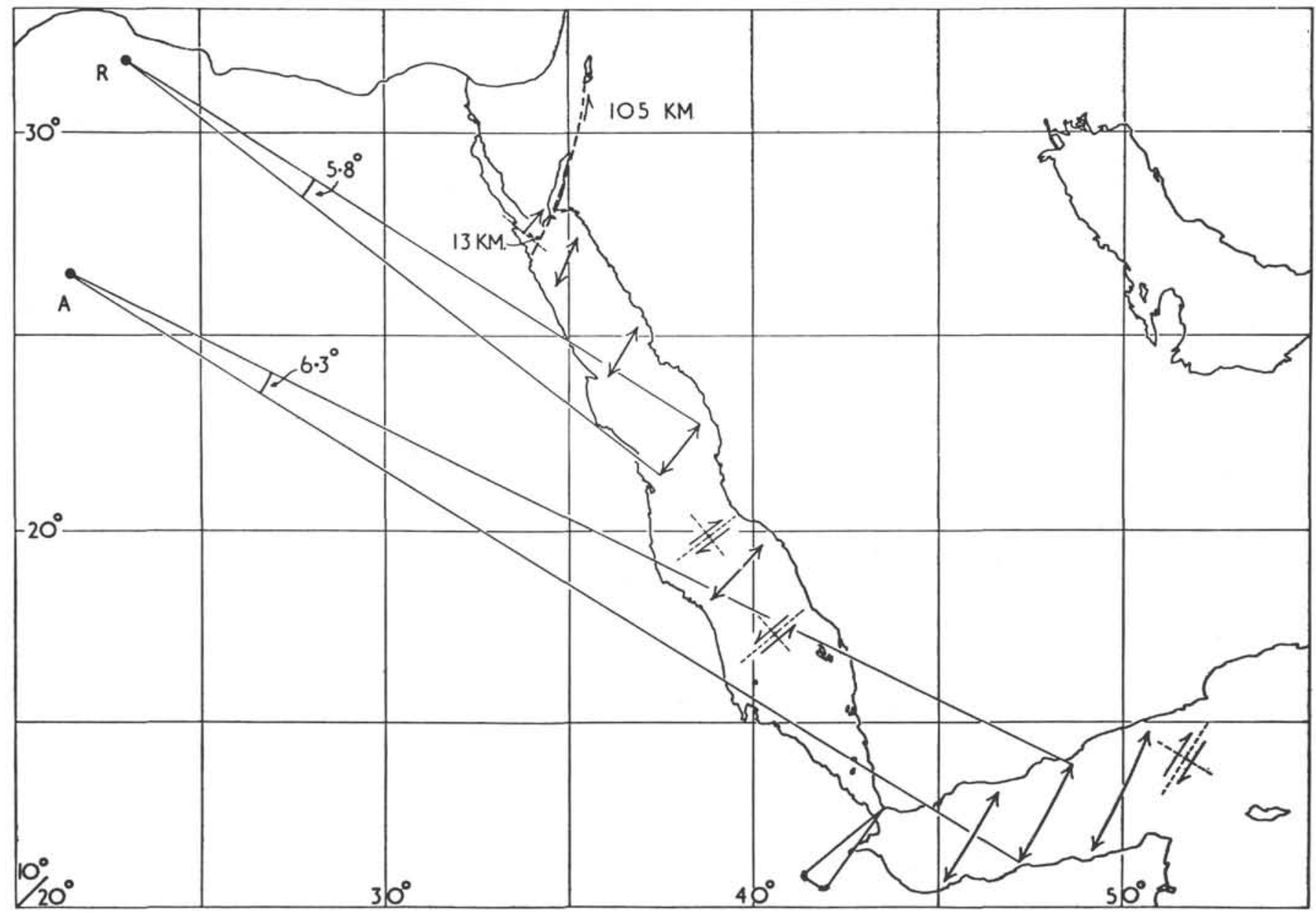

Figure 2. Poles of rotation for the Red Sea $(R)$ and Gulf of Aden (A). The amount of shear along the Dead Sea Rift is shown together with the directions, and estimates of the amounts, of extension at various localities in the Red Sea and Gulf of Aden. The available fault plane solutions are also shown.

ship has been hampered by navigational hazards such as coral reefs. Laughton et al. (1970) were able to identify anomaly 5 in the Gulf of Aden and establish that there has been sea-floor spreading at a rate of about $1 \mathrm{~cm} / \mathrm{yr}$ over the last $10 \mathrm{~m} . \mathrm{y}$. (no older anomalies have yet been identified). This interpretation was not contradicted by the findings of DSDP Leg 24. Site 231 was drilled $80 \mathrm{~km}$ from the Somali shore, at a place about $40 \mathrm{~km}$ landward of anomaly 5 , where the oldest sediments are middle Miocene and overlie basaltic basement (E.T. Bruce, personal communication).

In view of the constraints of plate tectonics which imply that the Red Sea must have a similar spreading history to the Gulf of Aden, available magnetic data for the Red Sea were examined with the objective of looking for the presence of the distinctive anomaly 5. Although there are no surface ship data, various aeromagnetic surveys have been flown over the Red Sea margins. For example, in 1969 , Project Magnet flew eight profiles across the whole width of the Red Sea at $18^{\circ} \mathrm{N}$. Four of these were at a height of 305 meters $(1000 \mathrm{ft})$ and four at a height of 3658 meters $(12,000 \mathrm{ft})$.

Figure 3 shows two of the Project Magnet profiles together with bathymetry taken from the chart of
Laughton (1970). The lower profile (flight height $305 \mathrm{~m}$ ) shows the large anomalies over the axial trough and reveals that smaller amplitude, longer wavelength anomalies do exist over the marginal zone. The upper profile (flight height $3658 \mathrm{~m}$ ) acts as a natural filter, and only the larger features of the lower profile are seen. If the anomalies over the marginal zone are associated with oceanic crust formed by sea-floor spreading, as seems likely because of their symmetry, then it is seen that details of the spreading history are lost even at the lower flight height. This is in all probability due to the large thickness of sediments over the marginal zone. These have been proved in exploration boreholes (see, for example, Girdler, 1970), and the magnetometer at the lower flight height could well be more than $5 \mathrm{~km}$ above the oceanic layer.

To try to discover more about the Red Sea spreading history, simulated profiles have been computed for various spreading models at various heights. Three such profiles are shown in Figure 4 for flight heights 0,2 , and $4 \mathrm{~km}$ and a spreading rate of $1 \mathrm{~cm} / \mathrm{yr}$ extending from 0 to $15 \mathrm{~m} . \mathrm{y}$. B.P. For simplicity, the oceanic layer is kept at a constant depth ( -2 to $-4 \mathrm{~km})$ as by looking at profiles for different heights allows one to observe the effects of changes of 


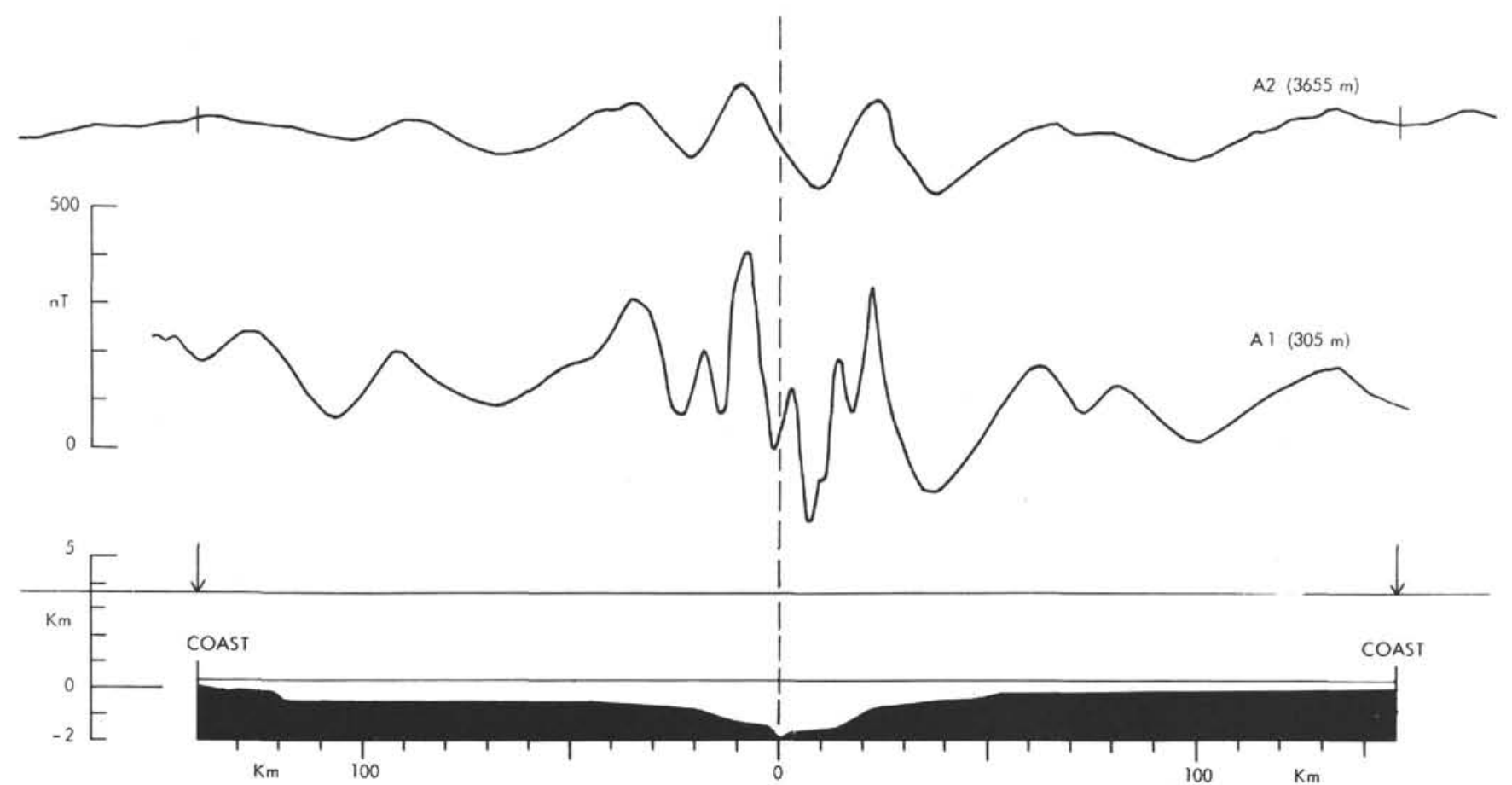

Figure 3. Project Magnet total intensity profiles across the Red Sea at $18.3^{\circ} \mathrm{N}$ showing the existence of large amplitude anomalies over the axial trough and smaller, longer wavelength anomalies over the marginal zone (after Darracott et al., 1973).

depth to the oceanic layer. It is noted that for the northwesterly orientation of the Red Sea, peaks occur over the west side of a normally magnetized body and troughs over the east side. A comparison of the observed profiles of Figure 3 with the model profiles of Figure 4 shows that it is difficult to correlate the anomalies beyond about 3 m.y. (as previously noted by Vine, 1966). It seems that sea-floor spreading anomalies do exist over the main trough, but their interpretation must await further detailed studies. Over the axial trough the correlations are reasonably good, giving a spreading rate of about $0.9 \mathrm{~cm} / \mathrm{yr}$ per limb at $18^{\circ} \mathrm{N}$.

Whatever may be the correct identification of the lower amplitude magnetic anomalies, found over the marginal zone, there seems to be no doubt that the large amplitude anomalies found over the center of the Red Sea can be convincingly correlated with the calculated profile for, conservatively, the last 2.4 m.y. Using the Project Magnet profile A1 as a basis, together with the Red Sea pole of Girdler and Darracott (1972), the distance of the 2.4-m.y. isochron from the spreading axis can be calculated for the small circles passing through Sites 225, 227, and 228 (Table 1). The essential point of this paper is that at Site 227 material older than indicated by this isochron was found. Also, at Site 228 it can be inferred from the continuity of the $\mathrm{S}$ reflector to the northeast of the site that Miocene evaporites exist as close as $13.5 \mathrm{~km}$ from the center of the axial trough, again much closer than indicated by the 2.4 m.y. isochron.

\section{Gravity Anomalies}

It should be noted that in early interpretations of Red Sea gravity anomalies (Girdler, 1958) corrections were not made for the effects of light sediments on the sides. It was not until the deep exploration boreholes were sunk in the 1960 's that the vast thickness of sediments was realized, e.g., salt with a density of $2.15 \mathrm{~g} / \mathrm{cm}^{3}$ to a depth of 3867 $\mathrm{km}$ at Dhunishub-1 (Frazier, 1970). When corrections are made for these light sediments, the positive Bouguer gravity anomaly over the center of the Red Sea becomes much wider, and, hence, the extent of the intrusive zone is found to be much wider. Later interpretations by Phillips et al. (1969), Tramontini and Davies (1969), and Sowerbutts (1972) show that models deduced from the gravity data are consistent with the plate tectonic models of Girdler and Darracott (1972).

\section{Seismic Refraction Data}

The seismic refraction results fall into two groups, those with mean velocity $6.93 \pm 0.32 \mathrm{~km} / \mathrm{s}(N=8)$ and those with mean velocity $5.86 \pm 0.16 \mathrm{~km} / \mathrm{s}(N=7)$ The mean depth of the former is $4.82 \pm 1.05 \mathrm{~km}$ and of the latter is $4.25 \pm 1.78 \mathrm{~km}$. The former velocities are close to those found beneath oceanic ridges and are considered to be new oceanic crust; the latter are appropriate for downfaulted shield rocks (Drake and Girdler, 1964). The layer coverlying the $6.93 \mathrm{~km} / \mathrm{s}$ material has a mean velocity of $4.18 \pm$ $0.40 \mathrm{~km} / \mathrm{s}$ and mean thickness $3.17 \pm 1.24 \mathrm{~km}(N=8)$; the layer overlying the $5.86 \mathrm{~km} / \mathrm{s}$ material has a mean velocity of $3.94 \pm 0.53 \mathrm{~km} / \mathrm{s}$ and mean thickness $3.10 \pm 1.14 \mathrm{~km}(N$ $=7$ ). The differences are insignificant, and the material is considered to be mainly evaporites with possibly some volcanics. The velocity is comparable with the $4.2 \pm 0.4$ $\mathrm{km} / \mathrm{s}$ measured for the Red Sea rock salt (Wheildon et al., this volume). 


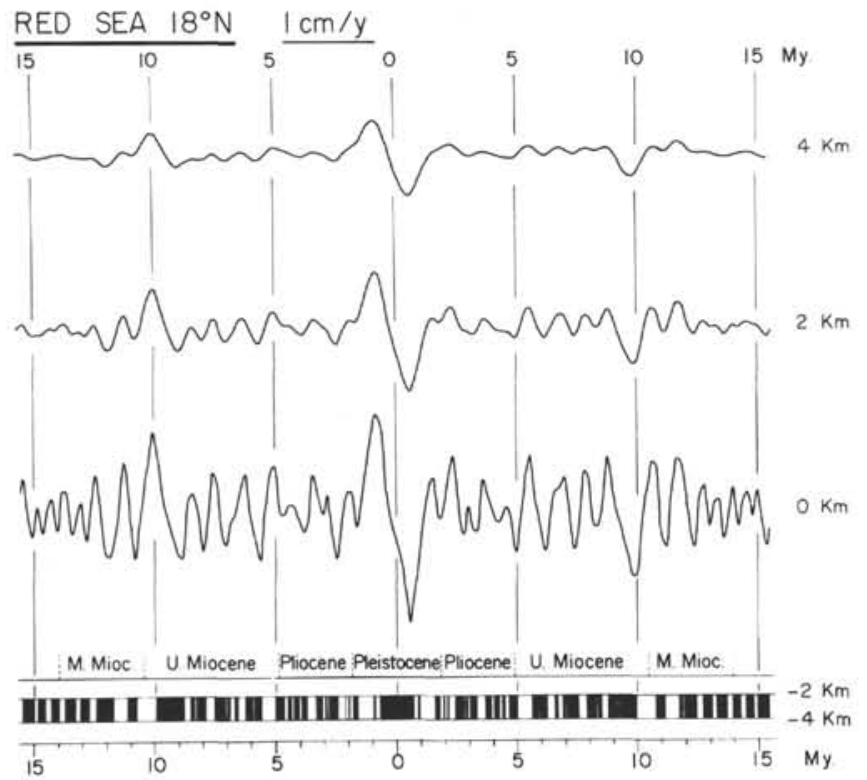

Figure 4. Simulated total intensity magnetic anomaly profiles for various altitudes over the Red Sea at $18^{\circ} \mathrm{N}$ with a spreading rate of $1 \mathrm{~cm} / y \mathrm{r}$ per limb, based on the reversal time scale of Heirtzler et al. (1968).

In general, the higher velocities $(6.9 \mathrm{~km} / \mathrm{s})$ are found towards the center of the Red Sea and the lower velocities $(5.9 \mathrm{~km} / \mathrm{s})$ near the margins. The one notable exception are profiles 175/176 (Drake and Girdler, 1964) which are seaward of the Dahlak Islands and near the axial trough. Here the velocity is $5.91 \mathrm{~km} / \mathrm{s}$, but the depth is unusually shallow (1.8 to $2.6 \mathrm{~km}$ ) suggesting it may be due to volcanic or anhydritic material within the evaporitic layer.

An intensive seismic refraction experiment (13 profiles) at $22.5^{\circ} \mathrm{N}, 37.0^{\circ} \mathrm{E}$ (Tramontini and Davies, 1969) shows oceanic velocities extending from the center of the Red Sea for a distance of $65 \mathrm{~km}$ towards the eastern margin, allowing a minimum estimate of $130 \mathrm{~km}$ for the width of new oceanic crust between Arabia and Nubia at this latitude. There is, therefore, considerable support from seismic refraction data for the plate tectonic model of Girdler and Darracott (1972).

TABLE 1

Calculated Red Sea Spreading History

\begin{tabular}{ccccc}
\hline Site & $\begin{array}{c}\text { Distance from } \\
\text { Center of Axial } \\
\text { Trough in } \\
\begin{array}{c}\text { Direction } 040^{\circ} \\
(\mathrm{km})\end{array}\end{array}$ & $\begin{array}{c}\text { Spreading } \\
\text { Rate for } \\
\text { last } 2.4 \mathrm{~m} . \mathrm{y} . \\
(\mathrm{cm} / \mathrm{yr})^{\mathrm{a}}\end{array}$ & $\begin{array}{c}\text { Inferred } \\
\text { Crystal Age } \\
(\mathrm{m} . \mathrm{y} .)\end{array}$ & $\begin{array}{c}\text { Inferred } \\
\text { Distance of } \\
2.4-\mathrm{m} . \mathrm{y} . \\
\text { Isochron from } \\
\text { Center of Axial } \\
\text { Trough } \\
(\mathrm{km})\end{array}$ \\
\hline 225 & 24 & 0.77 & 3.1 & 18.5 \\
227 & 9 & 0.77 & 1.2 & 18.5 \\
228 & 20 & 0.88 & 2.3 & 21.1 \\
\hline
\end{tabular}

${ }^{\mathrm{a}}$ Based on a rate of $0.94 \mathrm{~cm} / \mathrm{yr}$ at $18^{\circ} \mathrm{N}$ for the last $2.4 \mathrm{~m} . \mathrm{y}$., from Project Magnet Profile A1 and on the pole of Girdler and Darracott (1972).

\section{POSSIBLE EXPLANATIONS OF OBSERVATIONS}

At first sight there seem to be only two possible explanations for the observation of late Miocene evaporites overlying oceanic crust no older than late Pliocene, assuming that the absolute ages assigned to boundaries within the paleontological and magnetic time scales are essentially correct. The first possibility is that the observed magnetic anomalies have not been produced by sea-floor spreading or that, if they have been, they represent crust formed earlier than 2.4 m.y. ago. A strong argument in favor of a sea-floor spreading origin, besides the fit with calculated profiles based on the reversal time scale, is that the anomalies display the correct type of symmetry about the center line of the axial trough. The present seismic and volcanic activity of the Red Sea axis and the widespread lack of sediments in the axial trough indicate that sea-floor spreading is going on today, which must be a constraint on any spreading model, and only leaves the unlikely possibility that the spreading rate has been at a very much slower rate than about $1 \mathrm{~cm} / \mathrm{yr}$.

The second possibility is that the evaporites have moved towards the axial trough and over younger oceanic crust in post-Miocene times. This hypothesis is considered because of the known propensity of salt to flow and is examined in detail below. Coleman (this volume) has noted that the irregular topography of the axial trough at $16.67^{\circ} \mathrm{N}$ may have resulted from salt flowage.

\section{FLOWAGE OF SALT IN THE RED SEA}

\section{Mechanical Properties of Salt}

It has been shown by deep boreholes on the flanks of the Red Sea that the Miocene evaporites are largely composed of halite (salt) with subordinate amounts of anhydrite, dolomite, and shale. These findings were confirmed by holes drilled by Glomar Challenger near the center of the Red Sea. Thus, in considering possible ways in which the evaporites may have moved towards the center of the Red Sea, it is reasonable to confine our attention to the mechanical properties of salt.

There are many examples of natural flowage of salt, and these sometimes occur even on the surface (Kent, 1958; 1970). Laboratory experiments show that salt becomes more resistant to deformation as confining pressure increases, but that its strength decreases quite rapidly with increasing temperature. For example, Borchert and Muir (1964) describe experiments on two mined samples of halite subjected to a stress of $200 \mathrm{~kg} / \mathrm{cm}^{2}$ and to temperatures of $18^{\circ} \mathrm{C}$ and $36^{\circ} \mathrm{C}$, respectively. Although the cooler sample stopped creeping after 6 months, the hotter sample was still creeping at an almost undecreasing rate after $7 \frac{1}{2}$ months. Further, these authors point out that in nature, flowage at a depth of 2700 meters would occur at least 10 times faster than at the surface due to the greater importance of the increased temperature at that depth. Heard (1972) has also shown that the behavior of salt depends on the strain rate. There does not seem to be agreement in the literature on the exact conditions under which salt begins to flow, but recently Heard (1972) has published the results of an extensive series of experiments on annealed isotropic aggregates of halite at confining 
pressures of 2 kbars. He showed that for a strain rate of $1.54 \times 10^{-8} \mathrm{sec}^{-1}$, steady-state flow will occur at $100^{\circ} \mathrm{C}$. For geologically representative strain rates $\left(10^{-11}\right.$ to $10^{-15}$ $\mathrm{sec}^{-1}$ ) steady-state flow may exist at temperatures as low as $50^{\circ} \mathrm{C}$.

Downhole temperature measurements made during Leg 23 suggest that the temperature at the top of the evaporites is between $40^{\circ}$ and $80^{\circ} \mathrm{C}$. By extrapolating the observed temperature gradients down into the evaporites, after making allowance for the greater thermal conductivity of salt, it seems likely that temperatures of around $100^{\circ} \mathrm{C}$ exist within 1400 meters of the sea bed (Table 2). The total thickness of the Miocene evaporites adjacent to the DSDP boreholes is unknown, but a single deep well (B-1) drilled close to the axial trough in the southern Red Sea indicated that at least 1500 meters of halite is present there (Hutchinson and Engels, 1972). Much greater thicknesses of halite were penetrated by wells along the margins of the Red Sea (Girdler, 1970). Thus, it is clearly possible for temperatures well in excess of $100^{\circ} \mathrm{C}$ to exist near the base of the evaporites within some tens of kilometers of the center of the Red Sea.

Although it has been demonstrated that the temperature may be sufficiently high for salt flowage to be initiated, no horizontal flowage will occur until a suitable stress is present, and flowage will cease as soon as the stress drops below the elastic limit of salt. It is possible that the stress which caused the salt to flow resulted from the lack of lateral support along the walls of the axial trough when this feature began to form during post-Miocene sea-floor spreading. Since the axial trough is generally deeper, relative to the adjacent marginal zone, than the postMiocene, sediments are thick, then salt cropping out on the sides of the axial trough would have been free to flow into the trough. The temperature of this salt could conceivably have been as high as $100^{\circ} \mathrm{C}$ near Sites 227 and 228 .

A different mechanism, suggested by N. Price, makes use of the impervious nature of evaporites. It is possible that fluids from depths of several kilometers could freely rise up faults or other channels in the rocks underlying the evaporites, but be prevented from migrating upward any further by the impervious evaporite strata. Thus, the fluid pressure could exceed the overburden pressure at the base of the evaporites, and these beds could "float" and slide downhill under gravity. This mechanism seems to imply that the whole thickness of the evaporite sequence would move as a unit. As an explanation for our observations at Sites 227 and 228, this hypothesis suffers from the disadvantage that the slope of the lower boundary of the evaporites is unknown, although there are probably planes within the evaporites parallel to the isobaths of the original basin and therefore sloping towards the axial trough.

Either, or both, of the two mechanisms proposed above may have been active. It should be added that petrographical examination of the salt cored by Glomar Challenger has failed to reveal any sign of flow structures (Stoffers and Kühn, this volume; D. Shearman, personal communication), but this is probably not significant since the greatest penetration into the evaporites was only 130 meters. It is not expected that the conditions at such relatively shallow depths would allow salt flowage.

\section{Evidence of Salt Flowage in Leg 23 Cores}

Salt flowage towards the axial trough might be expected to cause disturbance of the overlying sediments. Consequently, color photographs of the cores obtained by Glomar Challenger were studied for signs of postdepositional disturbance. It was found that, at each of the three sites where cores undisturbed by the coring process were recovered, the post-Miocene sediments could always be divided into an upper series without post-depositional deformation and a lower deformed series (Table 3 and Frontispiece). At Sites 225 and 227 the boundary between the series lay in the late Pliocene, and at Site 228 it lay in the early Pleistocene. The deformed sediments usually have irregularly shaped clasts, typically about $2 \times 0.5 \mathrm{~cm}$, sometimes looking drawn out with wispy protrusions or looking rather blocky, angular, and fractured so that the pieces of an originally larger clast are clearly visible. In one core, 227-20-4, the sediment has the appearance of a conglomerate. The clasts differ from burrows in their size (burrows are seen in the cores but rarely exceed $3 \mathrm{~mm}$ in diameter) and in their irregular sometimes angular shape

TABLE 2

Extrapolated Downhole Temperatures at Red Sea Sites

\begin{tabular}{|c|c|c|c|c|c|c|}
\hline Site & $\begin{array}{l}\text { Deepest } \\
\text { Downhole } \\
\text { Depth } \\
\text { (m) }\end{array}$ & $\begin{array}{c}\text { emperature } \\
\text { Distance } \\
\text { Above } \\
\text { Evaporites } \\
\text { (m) }\end{array}$ & $\begin{array}{c}\text { Temperature } \\
\left({ }^{\circ} \mathrm{C}\right)\end{array}$ & $\begin{array}{c}\text { Estimated } \\
\text { Temperature } \\
\text { Gradient } \\
\text { in Sediments } \\
\left({ }^{\circ} \mathrm{C} / \mathrm{km}\right)\end{array}$ & $\begin{array}{c}\text { Estimated } \\
\text { Temperature } \\
\text { at Top of } \\
\text { Evaporites } \\
\left({ }^{\circ} \mathrm{C}\right)^{\mathrm{a}}\end{array}$ & $\begin{array}{l}\text { Estimated } \\
\text { Depth of } \\
100^{\circ} \mathrm{C} \\
\text { Isotherm } \\
\text { from Top of } \\
\text { Evaporites } \\
(\mathrm{m})^{\mathrm{b}}\end{array}$ \\
\hline 225 & 78 & 100 & 29 & 92 & 39 & 1326 \\
\hline 227 & 159 & 65 & 41 & 117 & 48 & 889 \\
\hline 228 & 97 & 190 & 40 & 186 & 76 & 258 \\
\hline
\end{tabular}

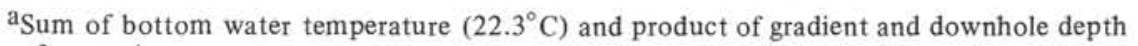
of evaporites.

${ }^{b}$ Assuming temperature gradient in evaporites is half that in sediments. Probably the gradients are slightly greater (Girdler, 1970) but this assumption makes greater allowance for unknown quantities of halite, the thermal conductivity of which is four times greater than that of the sediments (Wheildon et al., this volume). 
(burrows are typically circular or elliptical in cross-section). Not uncommonly, complete thin beds can be traced across a core with only a slight dip or deformation of the bed. Only at Site 228 was microfaulting seen in the sediments. The observations from Sites 225 and 227 are consistent with deformation of the sediments due to flowage of the underlying evaporites, up to late Pliocene times; at Site 228 the deformation of the sediments continued longer and was more severe, resulting in microfaulting and fairly steep dips of the bedding planes. This site lay close to a salt diapir, and the vertical movement of this feature probably caused the faulting and dips in contrast to the postulated predominantly horizontal motion at the other two sites.

TABLE 3

Core Disturbance at Red Sea Sites

\begin{tabular}{cccl}
\hline Core & Site 225 & Site 227 & Site 228 \\
\hline I & D & D & H \\
2 & & D & D \\
3 & H & H & D \\
4 & H & & H \\
5 & H & H & D \\
6 & H & X & H \\
7 & & & H \\
8 & D & X & D \\
9 & H & & \\
10 & D & D & H \\
11 & D & & H \\
12 & D & Xh & D F F \\
13 & H & X & D \\
14 & Xh & D & Xh \\
15 & Xh & X & D F F \\
16 & D & X & X \\
17 & X & X & \\
18 & Xh & X & X \\
19 & Xh & X & Xf \\
20 & X & XC & X \\
21 & X & & Xf \\
22 & Xh & Xh & Xf \\
23 & X & D + F & X \\
24 & anhydrite & D + F & Xf \\
25 & & D + F & X \\
26 & & D + F & Xf \\
27 & & D + F & X \\
28 & & D + F & X \\
29 & & D + F & Xf \\
30 & & anhydrite & Xf \\
31 & & & Xf \\
32 & & & X \\
33 & & & F \\
34 & & & F \\
35 & & & anhydrite \\
\hline
\end{tabular}

Note:

$\mathrm{D}=$ disturbed during drilling to extent that original structures destroyed;

$\mathrm{H}=$ horizontal banding present;

$\mathrm{X}=$ post-depositional deformation structures present, drawn out or angular clasts;

$\mathrm{Xh}=$ as $\mathrm{X}$, but some horizontal bands too;

$\mathrm{C}=$ conglomerate;

$\mathrm{F}=$ featureless sediment apparently undisturbed by coring;

$\mathrm{f}=$ microfaulting;

blank entries $=$ no color photographs available

\section{Evidence of Salt Flowage on Seismic Reflection Profiles}

Many kilometers of seismic reflection profile have now been obtained in the Red Sea with the S reflection (top of Miocene evaporites) clearly visible except over the axial trough (Knott et al., 1966; Phillips and Ross, 1970; Ross and Schlee, in press). Phillips and Ross (1970) summarized the characteristics of 20 profiles obtained across the main trough north of $17^{\circ} \mathrm{N}$ and gave the following description: "The uniform character of the $\mathrm{S}$ reflector should be emphasized. It is generally a distinct multiple echo sequence extending over a 0.1 to $0.2 \mathrm{sec}$ time interval, much like the sequence returning from the sea floor. The attitude of this reflector with respect to the layers above and below should be noted. In the flank regions of the main trough the reflecting horizons beneath appear to parallel it in a continuous manner, while the reflecting sequences above, directly beneath the sea floor, are more flat lying. In some profiles a thin sequence above reflector $\mathrm{S}$ seems to be folded conformably with reflector S. Also there is little correspondence between the configuration of reflector S and the sea floor topography. The average thickness of materials above reflector $\mathrm{S}$ is relatively uniform across the flanks of the main trough.

"In contrast to these marginal regions, the central portions of the profiles north of about $25^{\circ} \mathrm{N}$ and those across the main/axial trough boundary show reflector $\mathrm{S}$ to shape the sea floor topography, and the total thickness of the layers above reflector S appears to decrease gradually toward the axial trough. In addition the thick-layered sequence beneath reflector $\mathrm{S}$ abruptly disappears. In several places reflector $\mathrm{S}$ appears to overlap acoustically opaque material, eventually becoming indistinguishable from this underlying opaque material. In certain other profiles it appears to crop out on the steep walls of the axial trough. Reflector S can usually be traced to within 5 to $10 \mathrm{~km}$ of the axial trough."

Phillips and Ross (1970) explain the decreasing degree of folding upward in the seismic profiles by two phases of deformation, the later of which resulted from the initial phases of the present sea-floor spreading episode. This explanation seems unlikely since no clear-cut stages of deformation are apparent on their seismic profiles (nor on the Glomar Challenger-23 profiles), but instead there is a gradual decrease in folding intensity upward (Figure 5), and since it is hard to see how the initial phases of sea-floor spreading should cause folding of the sediments, it seems more likely that this folding can be explained by vertical salt tectonics. Further, the thinning of sedimenits overlying reflector $\mathrm{S}$, close to the edge of the axial trough, is consistent with flowage of the evaporites towards the trough, either because of stretching and thinning of the sediments carried on top of the evaporites or because the evaporites flowed over existing younger sediments. In the second case, what appears on the profiles would represent only the sediment laid down since the evaporites flowed as far as the edge of the axial trough. In either case reflector $\mathrm{S}$ would be expected to shape the sea-floor topography, as is observed. The disappearance of the thick-layered sequence beneath reflector S could simply be attributable to the chaotic structure of the evaporites after flowing towards the axial trough. 


\section{CONSEQUENCES OF SALT FLOWAGE}

In the early Pliocene the Red Sea was permanently invaded by the sea, deposition of evaporites ceased, and the lateral flowage of salt towards the axial trough together with deformation of overlying sediments began and probably quickly reached a maximum. It is possible that the lateral flowage of salt exceeded the spreading rate of the sea floor but as the salt thinned and/or cooled, the elastic stress limit was approached and the flowage ceased, perhaps in late Pliocene times as indicated by the results of Sites 225 and 227. Thinning of the salt is suggested by the behavior of the thickness of the $4.3 \mathrm{~km} / \mathrm{sec}$ layer (evaporites + volcanics) detected by Tramontini and Davies (1969) at $22^{\circ} \mathrm{N}$. The maximum thickness of evaporites penetrated by Glomar Challenger was 130 meters at Site 227. After flowage of the salt stopped, the evaporite sequence was carried passively away from the axis of the Red Sea by sea-floow spreading, giving rise to the apparently salt-free axial trough which is observed today. This sequence of events is summarized in Figure 6. In this figure a distinction is made between lateral flow of evaporites towards the axial trough, which ceased when the elastic limit of salt was reached, and vertical salt tectonics (diapirism), which is driven by the overburden pressure of the post-Miocene sediments and which therefore can continue as long as a source of salt remains.

\section{CONCLUSIONS}

The only convincing explanation for the presence of late Miocene evaporites and early Pliocene sediments at Sites 227 and 228, where they apparently overlie younger magnetic crust, is that the evaporites have moved towards the center of the Red Sea after they were deposited. In so doing, they carried the overlying sediments with them, and these were slightly deformed in the process. The exact mechanism by which the evaporites moved is not certain but seems to depend on the ease with which beds of salt can flow. The high heat flow of the central Red Sea will have assisted the salt flowage.

The whole Red Sea, to within $52 \mathrm{~km}$ of the coast, appears to be underlain by oceanic crust, formed by sea-floor spreading. The calculation of the horizontal distance over which the salt has flowed depends on the age which is assigned to the broad magnetic anomalies found adjacent to the axial trough. The salt began to flow at an unknown date, but judging by the deformation of cored sediments, it appears to have ceased flowing horizontally in late Pliocene times.

\section{REFERENCES}

Amann, H., 1972. Marine raw material exploration with the 'Valdivia': Meerestechnik, v. 3, p. 102-106.

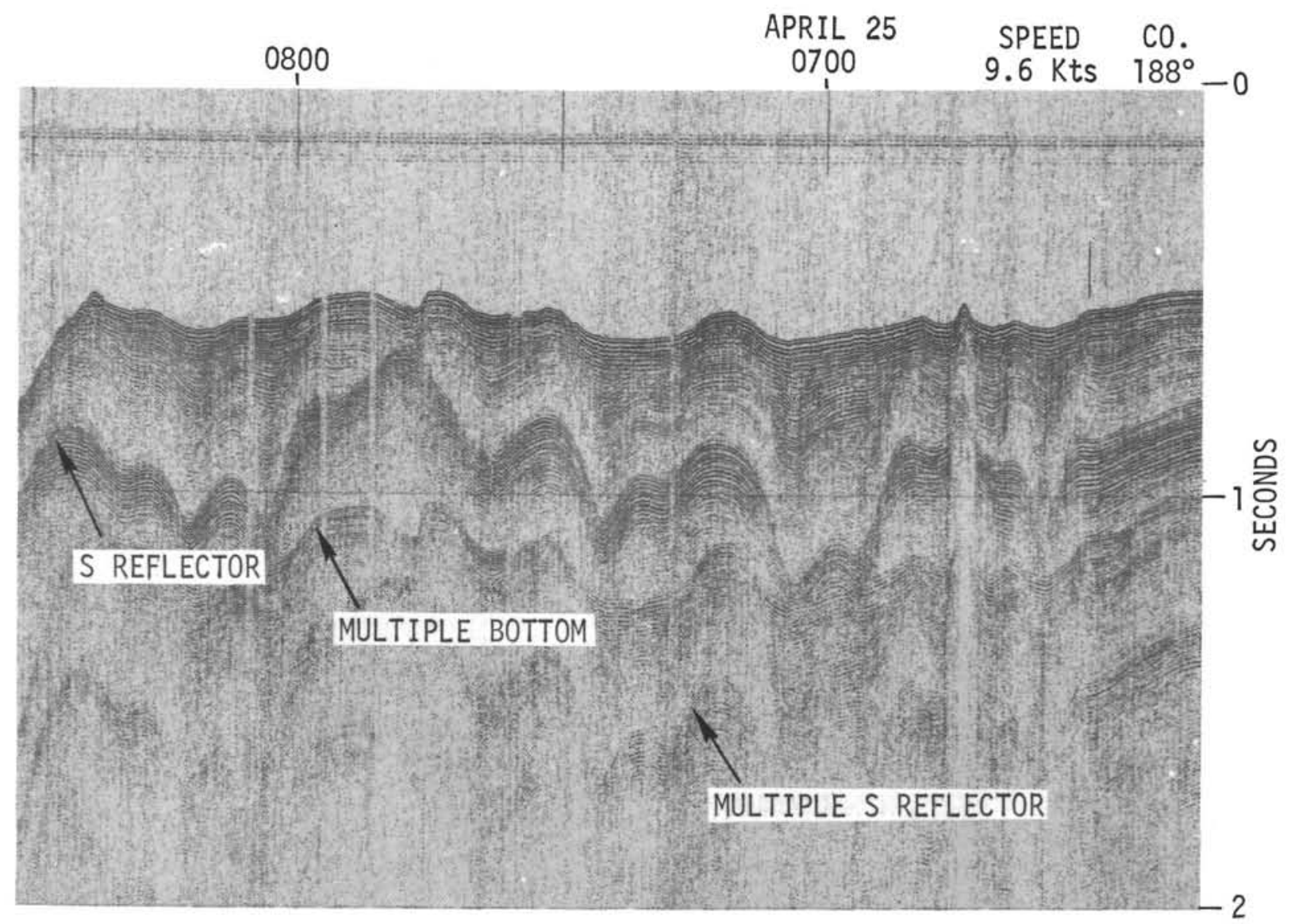

Figure 5. Reflection profile from about $18^{\circ} \mathrm{N}, 39^{\circ} \mathrm{E}$ to illustrate the gradual decrease in folding upwards above the $S$ reflector, from Glomar Challenger. Note the multiple reflection; the bottom echo is about $0.07 \mathrm{~s}$ long (two-way time). 


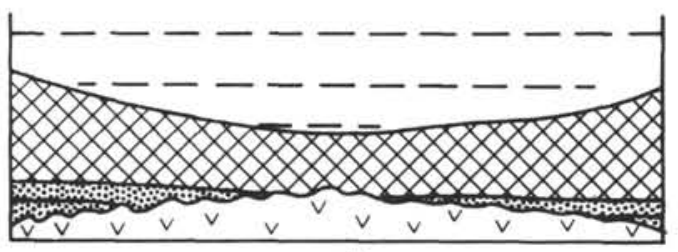

(a)

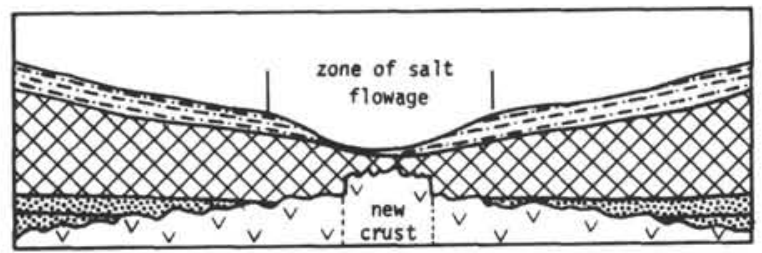

(b)

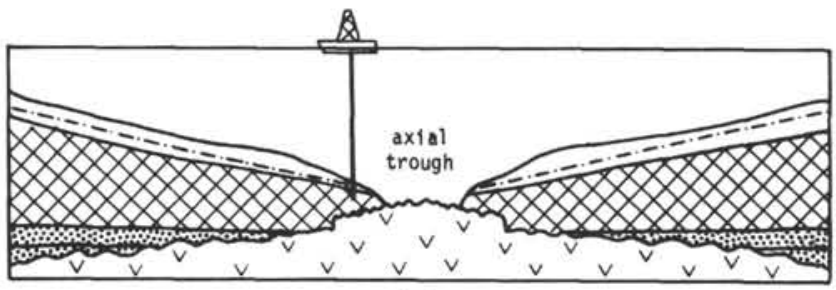

(c)

Figure 6. Diagram to illustrate the stages of development of the center of the Red Sea as envisaged in this paper (not to scale). (a) Late Miocene situation, deposition of evaporites, fluctuating sea level due to evaporation, (b) Pliocene situation, new ocean crust forming by seafloor spreading from ca. $2.4 \mathrm{~m} . \mathrm{y}$. ago, lateral flowage of evaporites into the center of the Red Sea, (c) Quaternary situation, salt flowage ceased, widening axial trough formed by continuing sea-floor spreading. Key $V=$ basaltic ocean crust, $L=$ evaporites, ..... preevaporite sediments, .-.-. postevaporite sediments.

Borchert, H. and Muir, R. O., 1964. Salt deposits: D. Van Norstrand Co. Ltd.

Darracott, B. W., Fairhead, J. D., Girdler, R. W., and Hall, S. H., 1973. The East African Rift System. In Implications of Continental Drift to the Earth Sciences: Tarling, D. H. and Runcorn, S. K. (Eds.), New York (Academic Press), p. 757-766.

Drake, C. L. and Girdler, R. W., 1964. A geophysical study of the Red Sea: Geophys. J. Roy. Astr. Soc., v. 8, p. $473-495$.

Frazier, S. B., 1970. Adjacent structures of Ethiopia: that portion of the Red Sea coast including Dahlak Kebir Island and the Gulf of Zula: Phil. Trans. Roy. Soc. Lond., A, v. 267, p. 131-142.

Freund, R., Garfunkel, Z., Zak, I., Goldberg, M., Weissbrod, T., and Derin, B., 1970. The shear along the Dead Sea rift: Phil. Trans. Roy. Soc. Lond., A, v. 267, p. 107-126.

Girdler, R. W., 1958. The relationship of the Red Sea to the East African Rift system: Quart. J. Geol. Soc., London, v. 114, p. 79.

Girdler, R. W., 1966. The role of translational and rotational movements in the formation of the Red Sea and Gulf of Aden, in The World Rift System: Geol. Surv. Canada paper $66-14$, p. 65.

Girdler, R. W., 1969. The Red Sea-a geophysical background. In Hot brines and recent heavy metal deposits in the Red Sea: Degens, E. T. and Ross D. A. (Eds.), New York (Springer Verlag), p. 38-58.

Girdler, R. W., 1970. A review of Red Sea heat flow: Phil. Trans. Roy. Soc. Lond., A, v. 267, p. 191-205.

Girdler, R. W. and Darracott, B. W., 1972. African poles of rotation. Comments on Earth Sciences: Geophysics, v. 2, p. 131-138.

Heard, H. C., 1972. Steady-state flow in polycrystalline halite at pressure of 2 kilobars: An. Geophys. Union Monograph 16, p. 191-209.

Heirtzler, J. R., Dickson, G. O., Herron, E. M., Pitman, W. C., and Le Pichon, X., 1968. Marine magnetic anomalies, geomagnetic field reversals and motions of the ocean floor and continents: J. Geophys. Res., v. 73, p. 2119-2136.

Hutchinson, R. W. and Engels, G. G., 1970. Tectonic significance of regional geology and evaporite lithofacies in northeastern Ethiopia: Phil. Trans. Roy. Soc. Lond., A, v. 267, p. 313-329.

Hutchinson, R. W. and Engels, G. G., 1972. Tectonic evolution in the southern Red Sea and its possible significance to older rifted continental margins: Geol. Soc. Am. Bull., v. 83, p. 2989-3002.

Kent, P. E., 1958. Recent studies of south Persian salt plugs: Am. Assoc. Petrol. Geol. Bull., v. 42, p. 2951-2972.

Kent, P. E., 1970. The salt plugs of the Persian Gulf region: Leicester Lit. Phil. Soc. Trans., v. 64, p. 56-88.

Knott, S. T., Bunce, E. T., and Chase, R. L., 1967. Red Sea seismic reflection studies in The World Rift System: Geol. Surv. Canada, paper 66-14, p. 33-61.

Laughton, A. S., 1970. A new bathymetric chart of the Red Sea: Phil. Trans. Roy. Soc. Lond., A, v. 267, p. 21-22.

Laughton, A. S., Whitmarsh, R. B., Jones, M. T., 1970. The evolution of the Gulf of Aden: Phil. Trans. Roy. Soc. Lond., A, v. 267, p. 227-266.

Lowell, J. D. and Genik, G. J., 1972. Sea-floor spreading and structural evolution of the southern Red Sea: Am. Assoc. Petrol. Geol. Bull., v. 56, p. 247-259.

McKenzie, D. P., Davies, D., and Molnar, P., 1970. Plate tectonics of the Red Sea and East Africa: Nature, v. 226, p. 243-248

Phillips, J. D., Woodside, J., and Bowin, C. O., 1969. Magnetic and gravity anomalies in the Central Red Sea. In Hot brines and recent heavy metal deposits in the Red Sea: Degens, E. T. and Ross, D. A. (Eds.), New York (Springer Verlag), p. 98-113.

Phillips, J. D. and Ross, D. A., 1970. Continuous seismic reflection profiles in the Red Sea: Phil. Trans. Roy. Soc. Lond., A, v. 267, p. 143-152.

Robson, D. A., 1970. Suez rift: Nature, v. 228, p. 1237.

Ross, D. A. and Schlee, J., in press. Shallow structure and geologic development of the southern Red Sea: Geol. Soc. Am. Bull.

Sowerbutts, W. T. C., 1972. Long gravity and magnetic profiles over the East African rift system and their interpretation. Unpublished Ph.D. thesis, the University, Newcastle upon Tyne.

Tramontini, C., Davies, D., 1969. A seismic refraction survey in the Red Sea: Geophys. J. Roy. Astr. Soc., v. 17,2 , p. $225-241$.

Vine, F. J., 1966. Spreading of the ocean floor, new evidence: Science, v. 154, p. 1405-1415. 